\section{Eco-Management and Audit \\ Scheme (EMAS) \\ implementation in \\ the European Union: \\ survey of Estonian \\ certified organisations}

\section{Krislin Kivi, Natalja Gurvits}

Tallinn University of Technology, Akadeemia tee 3, Tallinn 12618, Estonia

krislinkivi@gmail.com; natalja.gurvits@ttu.ee

\section{$\Gamma$} crossef

http://dx.doi.org/10.5755/j01.eis.0.11.17982

Nowadays the EU Eco-Management and Audit Scheme (EMAS) is considered as one of the most credible and effective environmental management tools, which adds valuable elements to an effective environmental management system. However, the number of EMAS registered companies in Estonia remains low, therefore the authors considered it useful to reveal the main reasons of this phenomenon and determine the main obstacles and benefits of EMAS implementation.

The main aim of the research was to find out positive and negative aspects associated with the EMAS certification and implementation; the role of EMAS for the stakeholders and the added value derived from the EMAS implementation.

The authors conducted interviews and distributed a questionnaire among the EMAS certified organisations in April-May 2015. The main findings of the research suggest that the most substantial value added by the EMAS system is the improved reputation, credibility and transparency derived from the preparation and publication of environmental reports, which is a compulsory component of EMAS. Organisations also recognized an added value of EMAS by the improved environmental performance. However, EMAS seemed to have less or no effect on other aspects such as risk management and employee motivation. Based on the results of the research it may be concluded that the value added to organisations by the implementation of EMAS was not significant. Even though implementation of EMAS brings along numerous positive impacts, it is also considered as time, money and effort consuming. Authors believe that more initiatives from the state side are strongly required to promote EMAS implementation and to increase the public awareness of the EMAS system, its main benefits and added values.

KEYWORDS: added value, certification, European Union, Eco-Management and Audit Scheme (EMAS), implementation.
EIS 11/2017

Eco-Management and Audit Scheme (EMAS) implementation in the European Union: survey of Estonian certified organisations

Submitted 04/2017

Accepted for publication 08/2017

\section{Abstract}

\section{ktu}

European Integration Studies No. $11 / 2017$

pp. $211-219$

DOI 10.5755/j01.eis.0.11.17982 (c) Kaunas University of Technology 
Introduction and literature review
Nowadays the European Union (EU) is playing a leading role in international efforts to promote sustainable development and responsible environmental performance. The growing importance of Corporate Social Responsibility in general and environmental performance of organisations in particular; as well as environmental policies and regulations introduced and enforced by the EU; made organisations to focus on the implementation of various environmental management systems.

However, much has been argued about why companies should voluntarily adopt various social and environmental initiatives. According to Nash \& Ehrenfeld (2001) many companies are adopting Environmental Management Systems (EMS) due to growing external pressure; this decision is not always necessarily linked to the conscious choice of making investments for improving the environmental performance of an entity. Arora \& Cason (1996) concluded that public recognition is key to improving the success of voluntary environmental regulation. This is also supported by the findings of Kagan et al. (2003) which suggest that some companies may show better performance compliance than other due to the pressures from local communities and environmental activists as well as the corporate management style. An important role is also played by trade associations and environmental groups by influencing companies to take voluntary actions towards the implementation of various regulatory programs to prevent potential harms (Koski \& May, 2006). It becomes evident that a "social licence to operate“ may be considered as an intangible asset of most companies and even industries; this asset, however, needs constant update and revaluation and according to Berger (2011) can be easily lost, which in turn couldbring serious negative consequences for the company.

Gunningham (2009) also noted that ,the empowering social license may be a particularly powerful point of leverage and that for large, highly visible corporations 'reputation risk' is becoming increasingly difficult to ignore".

All these developments have influenced companies to implement voluntarily various environmental management tools among which Eco-Management and Audit Scheme (EMAS) is considered as one of the most credible and effective tools, which adds valuable elements to an effective environmental management system.

The history of EMAS dates back to 1990 when it was first presented by the EU Commission as a mandatory scheme, however in response to the industry feedback it was changed to a voluntary standard (Franke, 1995). In July 1993 the EMAS Regulation 1836/93 was first introduced by the European Commission as a vital tool of environmental policy aiming to fulfil its goal of sustainable development; since April 1995 EMAS has been opened for voluntary participation, but its scope initially restricted participation to companies in the industrial sector (European Commission). The first pilot schemes confirmed that EMAS would improve environmental efficiency and promote good and responsible environmental performance (Counsell \& King, 1995), which is "significantly associated with "good" economic performance" (Al-Tuwaijri et al., 2003).

However, the research of Freimann \& Schwaderlapp (1996) showed that the audit system was quite complicated and had yet to reach its potential as companies concentrated their activities on documentation and self-control (Freimann \& Schwaderlapp, 1996). Research findings obtained shortly after the EMAS implementation revealed that the industry did require some form of environmental reporting (Erskine and Collins, 1996), but the implementation of EMAS was associated with certain difficulties and benefits (Hillary, 1998). Organisations mentioned lack of technical skills for environmental reporting and auditing, as well as difficulties faced by companies in preparation of the environmental report, but they also recognized various opportunities related to marketing, sales and publics relations arising as a result of the EMAS 
implementation (Strachan et al. 1997), therefore, confirming the ability of EMAS to become an efficient marketing tool for improvement of environmental performance (Strachan, 1995).

Findings of Mora \& Martin (1998) indicated that education and training should be the main tools required for the implementation of EMAS (Mora \& Martin, 1998). The results of first surveys carried out after the EMAS implementations introduced mixed opinions indicating the pessimistic estimation about the future of EMAS (Glachant et al., 2002), the low uptake of EMAS and indicating it as "communication tool of variable value" (Hillary, 1998), and also outlining that while the EMAS implementation is associated with several costs it also results in cost savings and numerous corporate benefits (Freimann \& Schwedes, 2000).

First revision of EMAS (EMAS II) took place in 2001 by the extension of the scope and the integration of the international environmental management system standard EN ISO 14001. As a result, EMAS was considered to become a vital tool to cope with environmental challenges and improve the competitive position of companies, which is also confirmed by studies of Jirillo et al., 2003.

Second revision took place in 2009 and on the $11^{\text {th }}$ of January 2010 the so called "EMAS III" (Regulation (EC) No 1221/2009) came into effect. EMAS III included the following new elements: introduction of EMAS Global, revised audit cycles to further improve applicability for SMEs, corporate registrations to ease administrative and financial burdens on organisations with several EMAS registered sites and environmental core indicators to adequately document environmental performance. (EU Commission)

Today the European Union EMAS brochure specifies the following nine good reasons for EMAS: resource efficiency, climate protection, corporate social responsibility, legal compliance, supply chain management and Green Public Procurement, credible information, performance measurement, employee agreement, and stakeholder involvement (EMAS Brochure, 2016). It should be outlined that EMAS goes beyond ISO 14001 by adding value through:

- Environmental performance - stricter requirements on the measurement and evaluation of environmental performance against objectives and targets, and the continuous improvement of that environmental performance;

- Legal security - compliance with environmental legislation ensured by government supervision;

\section{Strong employee involvement;}

\section{Environmental core indicators creating multi-annual comparability within and between organisations;}

_ Transparent communication - provision of information to the general public through the validated environmental statement; and

_ Reliability - registration by a public authority after verification by an accredited/licensed environmental verifier (EMAS - Factsheet, 2017)

The main differences of EMAS and ISO14001 are presented in Table 1.

From Table 1 it becomes evident that having much in common with ISO14001, EMAS requires more attention and participation from the management side, involvement of employees, preparation of an environmental report, sets out strict audit and verification rules and procedures. That in turn requires professional advice on the EMAS implementation to be available for all companies, special attention and support for SMEs, and various opportunities for different organisations to share EMAS related experience. Strong governmental support and influence of stakeholders are additional key factors in voluntary implementation of environmental management systems in general and EMAS 
Table 1

The main differences between EMAS and IS014001

\begin{tabular}{|c|c|c|}
\hline Elements & EMAS & IS014001 \\
\hline \multicolumn{3}{|c|}{ General aspects } \\
\hline Legal status & European Regulation (EC) No 1221/2009 & $\begin{array}{l}\text { International, commercial standard under } \\
\text { private law }\end{array}$ \\
\hline Participation & Voluntary & Voluntary \\
\hline Logo & Yes & No \\
\hline $\begin{array}{l}\text { Focus and } \\
\text { objective }\end{array}$ & $\begin{array}{l}\text { Focus on continual improvement of environ- } \\
\text { mental performance of the organisation }\end{array}$ & $\begin{array}{l}\text { Focus on continual improvement of the } \\
\text { Environmental Management System }\end{array}$ \\
\hline
\end{tabular}

\section{Planning}

\begin{tabular}{l|l|l}
\hline $\begin{array}{l}\text { Environmen- } \\
\text { tal aspects }\end{array}$ & $\begin{array}{l}\text { Comprehensive initial environmental review } \\
\text { of the current status of activities, products and } \\
\text { services }\end{array}$ & $\begin{array}{l}\text { - Requires only a procedure to identify } \\
\text { environmental aspects } \\
\text { Initial review is recommended, but not } \\
\text { required }\end{array}$ \\
\hline $\begin{array}{l}\text { Legal } \\
\text { compliance }\end{array}$ & Proof of full legal compliance is required & $\begin{array}{l}\text { Only commitment to comply with ap- } \\
\text { plicable legal requirements } \\
\text { No compliance audit }\end{array}$ \\
\hline $\begin{array}{l}\text { Employees } \\
\text { involvement }\end{array}$ & $\begin{array}{l}\text { Active involvement of employees and their } \\
\text { representatives }\end{array}$ & $\begin{array}{l}\text { Not required (ISO 14001 and EMAS both } \\
\text { foresee training for employees) }\end{array}$ \\
\hline $\begin{array}{l}\text { Suppliers and } \\
\text { contractors }\end{array}$ & $\begin{array}{l}\text { Influence over suppliers and contractors is } \\
\text { required }\end{array}$ & $\begin{array}{l}\text { Relevant procedures are communicated } \\
\text { to suppliers and contractors }\end{array}$ \\
\hline $\begin{array}{l}\text { External } \\
\text { communica- } \\
\text { tion }\end{array}$ & $\begin{array}{l}\text { Open dialogue with external stakeholders } \\
\text { is required } \\
\text { External reporting is required on the basis of a } \\
\text { regularly published environmental statement }\end{array}$ & $\begin{array}{l}\text { Dialogue with external stakeholders } \\
\text { not required } \\
\text { External reporting is not required }\end{array}$ \\
\hline
\end{tabular}

\section{Audit and verification}

\begin{tabular}{|c|c|c|}
\hline $\begin{array}{l}\text { Internal en- } \\
\text { vironmental } \\
\text { auditing }\end{array}$ & $\begin{array}{l}\text { _ Environmental Management System audit } \\
\text { _ Performance audit to evaluate environ- } \\
\text { mental performance } \\
\text { _ Environmental compliance audit }\end{array}$ & $\begin{array}{l}\text { - Includes only the Environmental Man- } \\
\text { agement System audit of the require- } \\
\text { ments of the standard }\end{array}$ \\
\hline $\begin{array}{l}\text { Verifier/ } \\
\text { Auditor }\end{array}$ & $\begin{array}{l}\text { Environmental verifiers are accredited/licensed } \\
\text { and supervised by governmental bodies } \\
\text { _ Independence of the environmental verifier } \\
\text { is required }\end{array}$ & $\begin{array}{l}\text { - Certification bodies are accredited } \\
\text { through a national Accreditation body } \\
\text { - Independence of the auditor is recom- } \\
\text { mended }\end{array}$ \\
\hline Audits & $\begin{array}{l}\text { - Inspection of documents and site visits to } \\
\text { be carried out according to Regulation } \\
\text { _ Check for improvement of environmental } \\
\text { performance } \\
\text { - Data from environmental statement needs } \\
\text { to be validated }\end{array}$ & $\begin{array}{l}\text { - No certification rules in standard (other } \\
\text { standards for auditing and certification) } \\
\text { - Check of Environmental Management } \\
\text { - System performance, but no frequency } \\
\text { specified or required }\end{array}$ \\
\hline $\begin{array}{l}\text { Official } \\
\text { registration } \\
\text { by Authorities }\end{array}$ & $\begin{array}{l}\text { _ Publicly accessible register records each } \\
\text { organisation } \\
\text { _ Each registered organisation receives a } \\
\text { _ registration number }\end{array}$ & No official register \\
\hline
\end{tabular}


in particular (Boiral, 2007). However, today an increased certification of ISO14001 rather than EMAS is observed (Wätzold et al., 2001), with ISO 14001 "becoming the dominant international standard for assessing environmental management processes“" (Morrow \& Rondinelli, 2002), which also serves as a benchmark for the development and assessment of the environmental practices of various organisations (Rondinelli \& Vastag, 2000) and outnumbers the EMAS in most European countries (Bracke \& Albrecht J, 2007). The findings of Testa et al., 2013 suggested that EMAS is usually chosen by companies willing to achieve full transparency in their environmental accounting and reporting. The results of a review of EMAS in Greece carried out by Abeliotis (2006) revealed that a major benefit of EMAS as seen by companies turned out to be closer monitoring of the production process while the infrastructure upgrading was named to be the costliest aspect (Abeliotis, 2006). Unlike IS014001, EMAS seems to be quite costly, time and effort consuming, and requiring the involvement of all employees, which goes in line with findings of Pedersen (2007), stating that companies consider EMAS as a successful initiative, though in their opinion, costs associated with its implementation outweigh the benefits. In case of EMAS it seems obvious that since the very beginning costs remain the main barrier of implementation and renewal of certification even in case of high internal and external motivation of the organisation.

In 2009, Vernon et al. conducted surveys and interviews with the European EMAS registered organisations, and the results revealed that the greatest obstacle related to the implementation of EMAS appeared to be the associated costs while the most frequently named financial benefits were reductions in energy use and more efficient usage of resources. The findings also demonstrated different motivations of EMAS implementation: public sector organisations were mostly motivated by improved employee motivation and overall transparency while in case of the public sector organisation the main drivers were improved reputation for the organisation and requirements from the stakeholders' side (customers, supply chain) (Vernon et. al, 2009). It should also be noted that motivation varies among companies, industries and the sector of activity. The findings of the study of Alvarez-Garcia \& RioRama (2016) demonstrated that internal motivation related to improved productivity, efficiency and improved performance of the organisation has a stronger influence on the benefits derived from the EMAS implementation than the external ones related to demand from the stakeholders' side. Therefore, it is obvious that there are many ways to increase the initiatives of organisations to implement EMAS voluntarily, which is also confirmed by the studies of Kolln \& Prakash, (2002).

The results of a survey regarding the EMAS implementation conducted by Merli et al. (2016) among all Italian registered organisations revealed that the majority of the surveyed organisations would renew their EMAS registration, but public administrations seemed to be more satisfied with the EMAS. Public administrations also experienced higher difficulties relating to staff and, in particular, to lack of time and motivation but appeared to be more enthusiastic about the benefits achievable with EMAS. (Merli et al., 2016) These findings are in line with prior researches of Emilsson \& Hjelm (2004 \& 2005) stating that local authorities indicated an increased interest toward voluntary implementation of environmental management systems and have actively used EMAS for this purpose.

According to the official statistics of the European EMAS helpdesk the number of EMAS registered organisations in Europe is declining as illustrated by Figure 1. Statistical data shows that the peak of EMAS registered organisations was observed in April 2011, while in February 2017 the amount has dropped to its minimum since April 2010.

As of February 2017, there were 3658 organisations registered according to the EMAS scheme, in the EU. Germany (1160) is the leading country for the number of registered organisations, followed by Italy, Spain and Austria (929, 866 and 290 respectively) while at the end of the list 
Figure 1

Official statistics of the European EMAS helpdesk - Evolution of EMAS registered organisations

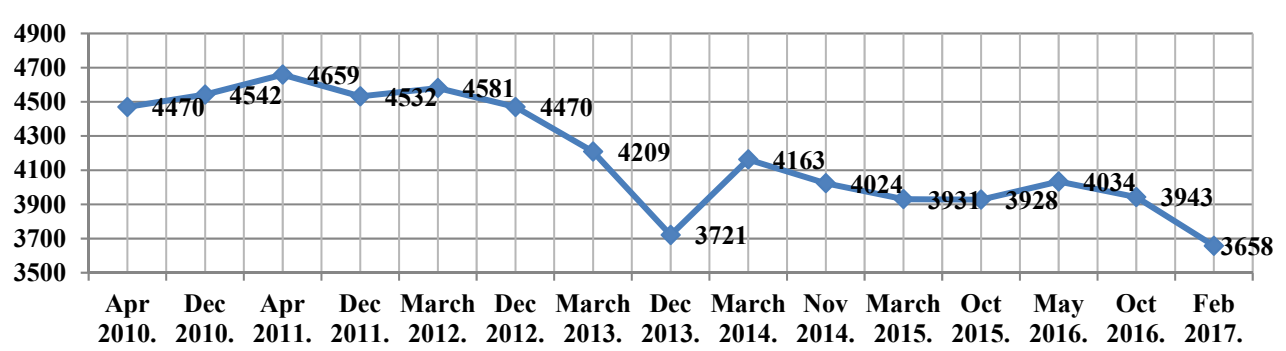

Source: EU EMAS register and German register.

remain Luxembourg, Netherlands and Malta (2,2 and 1) respectively. According to the official statistics of the European EMAS helpdesk no EMAS registered organisations were found in Croatia and Latvia, and only 6 Estonian organisations are EMAS registered. (EU Commission)

Despite the numerous studies carried out on the various benefits, obstacles and added values derived from the EMAS implementation, no such studies observe the current situation in Estonia, small European country, where the number of EMAS registered organisations still remains low. Therefore, the authors considered it vital and worth attention to reveal the main reasons of this phenomenon and determine the main obstacles and benefits.

The main aim of the research was to find out positive and negative aspects associated with EMAS certification and implementation; the role of EMAS for the stakeholders and the added value derived from the EMAS implementation. The added value was examined via improved environmental and financial performance, risk credibility, transparency and reputation, employee motivation and involvement.

For the present study the authors have chosen interviews as a method of qualitative research due to a small number of EMAS registered organisations. Interviews were conducted among the EMAS certified organisations in April-May 2015, five organisations were immediately available, for the two others the authors used a questionnaire, however later on one of these organisations also joined the interview process. In authors' opinion the results of the interview are still relevant and even more important in 2017 than in 2015 as since then two private sector organisations have cancelled their EMAS registration and one public sector organisation became EMAS registered in October 2015. Therefore, it seems very important to find out the main benefits and obstacles associated with EMAS registration in Estonia.

One of the main objectives of the interview was to find out the opinion of organisations on the EMAS certification process in general and the main problems and difficulties related to the process itself in particular. Most organisations outlined that they had to perform a huge amount of work related to preparation for the EMAS implementation, like collection and systematization of data, which was absolutely necessary to prepare the environmental report. Organisations also experienced difficulties related to the involvement of employees, especially in the public sector organisations with high percentage of office staff. These results were in line with findings of Merli et.al (2016), confirming that public administrations also experienced higher difficulties relating to staff involvement.

It seemed complicated to explain the necessity of EMAS implementation and certification to the personnel, especially in non-manufacturing non-ISO14001 certified organisations. It was also mentioned that even after the EMAS implementation the preparation of environmental reports still seemed to be a quite time-consuming process. Organisations also named costliness as one of the 
main problems related to certification and implementation; three organisations were of the opinion that costs were rather high. It is worth mentioning that IS014001 certified companies experienced less difficulties related to the EMAS implementation process, than the non-certified ones.

The authors also wanted to determine the added value derived from the EMAS implementation. The added value was examined via improved environmental and financial performance, risk credibility, transparency and reputation, employee motivation and involvement. The main findings of the research suggest that the most substantial value added by the implementation of the EMAS system is the improved reputation, credibility and transparency derived from the preparation and publication of environmental reports, which is a compulsory component of EMAS. Organisations also recognized an added value of EMAS by the improved environmental performance pointing out that their own environmental awareness had risen due to the implementation of an environmental performance measurement and evaluation system. However, EMAS seemed to have less or no effect on other aspects such as risk management and employee motivation.

During the interviews it became obvious that EMAS has little or no influence on the relations with stakeholders due to their low awareness of EMAS compared to IS014001. The feedback received by companies in regard to EMAS certification was low or "zero" in most cases. During the EMAS implementation phase, most organisations turned to professional consultants whose assistance in the process was highly valued and appreciated.

Nowadays the Eco-Management and Audit Scheme (EMAS) is considered as one of the most credible and effective environmental management tools, which adds valuable elements to an effective environmental management system and plays an important role in sustainable development reinforced by the European Union's renewed Sustainable Development Strategy (EU SDS). EMAS was designed to improve and promote sustainable and responsible environmental performance and resource-efficient production. However, it seems that in practice EMAS is not a widely used and recognized market tool for the implementation of an environmental management system. The low popularity and low awareness of EMAS among stakeholders in case of Estonia may partly be explained by the success of its "competitor" ISO14001, which has a certification process highly similar with EMAS, but is still less costly and easier in terms of process. The low number of EMAS certified companies in Europe confirm that even if EMAS is regarded by companies as a way to further successful and sustainable development, the benefits related to its implementation do not substantially outweigh the costs. In authors' opinion costliness might also be one of the factors which prevented companies from realizing the constantly growing importance and significance of non-financial reporting. Therefore, awareness should be raised in this regard so that companies start considering the preparation and publication of an environmental report as a vital part of their business strategy, activity and transparency and would regard costs, even substantial ones, as the essential investments into their reputation and risk-reduced activity.

Based on the results of the research it may be concluded that in case of Estonia the value added to organisations by the implementation of EMAS was not very significant. Even though the implementation of EMAS brings along numerous positive impacts, it is also considered as time, money and effort consuming. Authors believe that more initiatives from the state side are strongly required in order to promote EMAS implementation in both, private and public sector. Support is also needed in order to increase public awareness of EMAS system, its main benefits and added values. It may also be useful to create a national platform among EMAS registered companies to share experience, opinions and ways to reduce costs associated with the implementation of the system and consider them as a fee to obtain a "social licence to operate". 


\section{References}

Abeliotis,K.(2006). A review of EMAS in Greece: is it effective? Journal of Cleaner Production, 14(18): 1644-1647. doi: 10.1016/j.jclepro.2005.10.002. https://doi.org/10.1016/j.jclepro.2005.10.002

Al-Tuwaijri, S, Christensen, T. E. and Hughes, K.E. (2003). The Relations Among Environmental Disclosure, Environmental Performance, and Economic Performance: A Simultaneous Equations. 29(56): 447-471.doi: 10.1016/S0361-3682(03)00032-1. https://doi.org/10.1016/S0361-3682(03)00032-1

Alvarez-Garcia, J., RioRama, MD. (2016). Sustainability and EMAS: Impact of Motivations and Barriers on the Perceived Benefits from the Adoption of Standards. Sustainability 2016, 8(10), 1057; doi:10.3390/su8101057. https://doi.org/10.3390/ su8101057

Arora, S., Cason, TN (1996). Why do firms volunteer to exceed environmental regulations? Understanding participation in EPA's 33/50 program. Land Economics. 72(4): 413-432. doi: 10.2307/3146906. https://doi.org/10.2307/3146906

Berger C. 2011. Losing your social licence can hurt. The Age [Internet]; [cited 2011 Jul 19]. Available from: http://www.theage.com.au/business/losinga-social-licence-can-hurt-20110717-1hk1l.html.

Boiral, 0. (2007). Corporate greening through ISO 14001: A rational myth? Organisation Science. 18(1): 127-146.doi: 10.1287/orsc.1060.0224. https://doi.org/10.1287/orsc.1060.0224

Bracke R, Albrecht J. (2007). “Competing environmental management standards: How ISO 14001 outnumbered EMAS in Germany, the UK, France, and Sweden" Environment and Planning C: Government and Policy 25, 611-627 Google Scholar Abstract. https://doi.org/10.1068/c0602j

Counsell, D. and King, B. (1995), Implementation of environmental policy using the eco-management and audit scheme for UK local government: Experience in Cleveland. European Environment 5(4): 106-111. doi:10.1002/eet.3320050404. https://doi. org/10.1002/eet.3320050404

EMAS Factsheet. (2008). Third edition. Retrieved February 23, 2017 from http://www.emas.de/fileadmin/user_upload/04_ueberemas/PDF-Dateien/Unterschiede_iso_en.pdf

EMAS INFO. Retrieved February 23, 2017 from http://www.emas.de/fileadmin/user_upload/06_ service/PDF-Dateien/UGA_Infosheet_From-ISO14001-to-EMAS.pdf
EU Commission. European Union EMAS register. EMAS statistics. Retrieved March 06, 2017 from http://ec.europa.eu/environment/emas/emas_ registrations/statistics_graphs_en.htm

Emilsson, S. and Hjelm, O. (2004), Different approaches to standardized environmental management systems in local authorities - two case studies in Gothenburg and Newcastle. Corporate Social Responsibility and Environmental Management, 11: 4860. doi:10.1002/csr.54. https://doi.org/10.1002/csr.54

Emilsson, S. and Hjelm, O. (2005), Development of the use of standardized environmental management systems (EMSs) in local authorities. Corporate Social Responsibility and Environmental Management, 12: 144-156. doi:10.1002/csr.80. https:// doi.org/10.1002/csr.80

Erskine, C. and Collins, L. (1996), Corporate response of European paper companies to voluntary environmental policy initiatives. Eco-Management and Auditing, 3: 126-138. doi:10.1002/(SICI)10990925(199611)3:3<126: AID-EMA53>3.0.CO;2-H

Franke, J. (1995), Political evolution of EMAS: Perspectives from the EU, national governments and industrial groups. Environmental Policy and Governance, 5(6): 155-159. doi:10.1002/eet.3320050602. https://doi.org/10.1002/eet.3320050602

Freimann, J. and Schwaderlapp, R. (1996), Implementation of the EU's EMAS regulation in German companies. Eco-Management and Auditing, 3: 109112. doi:10.1002/(SICI)1099-0925(199611)3:3<109: AID-EMA54>3.0.CO;2-H

Freimann, J. and Schwedes, R. (2000), EMAS experiences in German companies: a survey on empirical studies. Eco-Management and Auditing, 7: 99-105. doi:10.1002/1099-0925(200009)7:3<99: AID-EMA135>3.0.CO;2-X

Gunningham, N. (2009), Shaping corporate environmental performance: a review. Environmental Policy and Governance, 19: 215-231. doi:10.1002/ eet.510. https://doi.org/10.1002/eet.510

Jirillo, R., Rocchi, A. and Martucci, O. (2003), EMAS and its local diffusion in Italy. Corporate Social Responsibility and Environmental Management, (10): 40-49. doi:10.1002/csr.24. https://doi. org/10.1002/csr.24

Hillary, R. (1998), Pan-European union assessment of EMAS implementation. European Environment, 8(6): 184-192. doi:10.1002/(SICI)10990976(199811/12)8:6<184: AID-EET175>3.0.CO;2-Z 
Glachant M, Schucht S, Bültmann A, Wätzold F. (2002). Companies' participation in EMAS: The influence of the public regulator. Business Strategy and the Environment, 11: 254-266. doi:10.1002/ bse.333. https://doi.org/10.1002/bse.333

Kagan, R. A., Gunningham, N. and Thornton, D. (2003), Explaining Corporate Environmental Performance: How Does Regulation Matter?. Law \& Society Review, 37: 51-90. doi:10.1111/1540-5893.3701002. https://doi.org/10.1111/1540-5893.3701002

Kolln, K., Prakash, A. (2002). EMS-based environmental regimes as club goods: Examining variations in firm-level adoption of ISO 14001 and EMAS in U.K., U.S. and Germany. Policy Sciences, 35(1): 43-67. https://doi.org/10.1023/A:1016071810725

Koski C, May PJ. (2006). Interests and implementation: fostering voluntary regulatory actions. Journal of Public Administration Research and Theory 16 : 329-349. https://doi.org/10.1093/jopart/mui048

Merli, R., Preziosi, M.,Ippolito, C (2016). Promoting Sustainability through EMS Application: A Survey Examining the Critical Factors about EMAS Registration in Italian Organisations. Sustainability. 8(3). 197. doi: 10.3390/su8030197. https://doi. org/10.3390/su8030197

Mora, E. P. and Martin, J. E. (1998), Environmental management systems within the university. Eco-Management and Auditing, 5: 136-145. doi:10.1002/(SICI)1099-0925(1998110)5:3<136: AID-EMA87>3.0.CO;2-7

Morrow, D., Rondinelli, D. (2002). Adopting corporate environmental management systems: Motivations and results of ISO 14001 and EMAS certification. European Management Journal. 20(2):159-171. doi: 10.1016/S0263-2373(02)00026-9. https://doi. org/10.1016/S0263-2373(02)00026-9

Nash J, Ehrenfeld J. (2001). Factors that shape EMS outcomes fn Firms. In Regulating from the Inside: Can Environmental Management Systems Achieve Policy Goals?, Coglianese J, Nash J (eds). Resources for the Future: Washington, DC; 61-81.
Pedersen, E. R. (2007), Perceptions of performance: how European organisations experience EMAS registration. Corporate Social Responsibility and Environmental Management, 14: 61-73. doi:10.1002/csr.118. https://doi.org/10.1002/ csr.118

Rondinelli, D.A and Vastag, G. (2000). Panacea common sense or just a label? The value of ISO 14001 environmental management systems. European Management Journal, 18 (5): 499-510. doi: 10.1016/S0263-2373(00)00039-6. https://doi. org/10.1016/S0263-2373(00)00039-6

Strachan, P. A. (1999), Is the Eco-Management and Audit Scheme (EMAS) Regulation an effective strategic marketing tool for implementing industrial organisations? Eco-Management and Auditing, 6: 42-51. doi:10.1002/(SICI)10990925(199903)6: 1<42: AID-EMA88>3.0.C0;2-G

Strachan, P., Haque, M., McCulloch, A. and Moxen, J. (1997), The Eco-Management and Audit Scheme: Recent experiences of UK participating organisations. European Environment, 7: 25-33. doi:10.1002/(SICI)1099-0976(199701)7:1<25: AID-EET97>3.0.CO;2-2

Testa, F., Rizzi,F., Daddi,T., Gusmerotti N.M., Frey, M, Iraldo,F. (2014). EMAS and ISO 14001: the differences in effectively improving environmental performance. Journal of Cleaner Production 68: 165-173. http://dx.doi.org/10.1016/j.jclepro.2013.12.061. https://doi.org/10.1016/j.jclepro.2013.12.061

Vernon, J., Peacoc, M., Belin, A., Ganzleben, C., \& Candell, M. (2009). Study on the Costs and Benefits of EMAS to Registered Organisations. Milieu Ltd.: Brussels, Belgium. Retrieved March 6, 20017 from http://ec.europa.eu/environment/emas/pdf/other/costs_and_benefits_of_emas.pdf

Wätzold, F., Bültmann, A., Eames, M., Lulofs, K. and Schucht, S. (2001), EMAS and regulatory relief in Europe: lessons from national experience. European Environment, 11: 37-48. doi:10.1002/eet.249. https://doi.org/10.1002/eet.249

\section{KIVI KRISLIN}

\section{MA}

Tallinn University of Technology

Fields of research interests

Environmental reporting, management, CSR

\section{Address}

Akadeemia tee 3, Tallinn 12618, Estonia

\section{GURVITS NATALJA \\ PhD}

Tallinn University of Technology

Fields of research interests

CSR, Accounting and Business Ethics, Sustainability Accounting and Reporting

\section{Address}

Akadeemia tee 3, Tallinn 12618, Estonia

\section{About the authors}

